\title{
Land Use Dynamics and Variations in Sprawl across Municipalities in the Bamenda Urban-scape from 1996-2018
}

\author{
Fombe Lawrence F. ${ }^{1} \&$ Acha Mildred E. ${ }^{2}$ \\ ${ }^{1}$ Higher Institute of Transport and Logistics, The University of Bamenda, Cameroon \\ ${ }^{2}$ Department of Geography and Planning, Faculty of Arts, The University of Bamenda, Cameroon \\ Correspondence: Fombe Lawrence F., HITL, The University of Bamenda, P.O. Box 39, Bambili, Cameroon. Tel: \\ 237-6-9603-1463. E-mail: ezumeh@hotmail.com
}

Received: May 15, 2020 Accepted: June 9, 2020 Online Published: July 30, 2020

doi:10.5539/jsd.v13n4p224 URL: https://doi.org/10.5539/jsd.v13n4p224

\begin{abstract}
Worldwide urban areas are having increasing influence over the surrounding landscape. Peri-urban regions of the world are facing challenges which results from sprawl with increasing problems of social segregation, wasted land and greater distance to work. This study seeks to examine the trends in land use dynamics, urban sprawl and associated development implications in the Bamenda Municipalities from 1996 to 2018. The study made use of the survey, historical and correlational research designs. The purposive and snowball techniques were used to collect data. Spatiotemporal analyses were carried out on Landsat Images for 1996, 2008, and 2018 obtained from Earth Explorer, Erdas Image 2014 and changes detected from the maps digitized. The SPSS version 21 and MS Excel 2016 were used to analyze quantitative and qualitative data. The former employed the Pearson correlation analysis. Analysis of land use/land cover change detection reveals that built-up area has increased significantly from 1996 to 2018 at the detriment of forest, wetland and agricultural land at different rates within each municipality. These changes have led to invasion of risk zones, high land values, uncoordinated, uncontrolled and unplanned urban growth. The study suggests that proactive planning, use of GIS to monitor land use activities, effective implementation of existing town planning norms and building regulations, are invaluable strategies to sustainably manage urban growth in Bamenda.
\end{abstract}

Keywords: Bamenda, dynamics, municipalities, peri-urban, sprawl

\section{Introduction}

The expansion of human populations away from city centre into low-density, mono-functional and usually cardependent communities is a process that has been operating in most towns of the world and in recent years is very rapid. Land use dynamics and variations in sprawl are interwoven phenomenon that are inevitable as long as humanity continue to exist on the earth's surface (Girardet, 1999). To live in sprawl means driving to work, driving to get dinner, driving to meet your friends. It means congestion, as its inhabitants travel ludicrous distances for work or basic services, and isolation due to the lack of the benefit of compact city life. Sprawl eats up huge areas in very inefficient ways, destroying arable land and creating monocultures. Furthermore, a sprawling metropolis generates vastly greater amounts of pollution and $\mathrm{CO}_{2}$ than a more compact one (Douglas, 2017).

Urban sprawl is a multifaceted concept that directly affects traffic congestion, high oil consumption and many other transportation issues (Brunner and Andrew, 2013 in Kimengsi, Balgah \& Achia, 2017). A recent study by WWF shows that in the last 25 years, some 33 percent of the natural world has been annihilated (The Living Planet Index, WWF, 1998 in Girardet, 1999). From the end of the $20^{\text {th }}$ century, humanity started turning themselves into urban species making large cities and towns their main habitat.

Peri-urban areas have assumed the central stage of physical, social and economic transformation both in developed and in the developing world. Dynamics in peri-urban areas are characterized by changing local economic and employment structures from agriculture to manufacturing, rapid population growth and migration, rising land values, mixed land uses and significant infrastructural development (Webster, 2002; Plurel, 2010 in Kimengsi et al.., 2017). Peri-urban land development often goes on in an unregulated manner and gives rise to complex urban structures which assume a horizontal expansion trajectory. The emerging land use by and large indicate a mismatch with the widely cherished planning norms and standards and land value theories, zoning and principles like the equitable provision of basic services including complimentarity in urban land development (Kombe, 2003). 
Further patterns of peri-urban growth seldom respect the laid down Master plans and even the Master Plan shows significant deviation from the preferred land suitability (Dutta, 2012; Kometa \& Ndi, 2012).

Urban sprawl manifests in different forms such as strip or ribbon sprawl, scattered, leapfrog, Polynucleated development among others. The urban population of the developed world is expected to grow from 0.9 billion to 1 billion by 2030, while that for the less developed world is expected to grow from 1.9 billion to 3.9 billion by 2030 (UNCHS Habitat, 2001). The ever-increasing population of the world has led to the rise of unplanned urban growth in the cities, usually termed urban sprawl (Theobald, 2001; Bugliarello, 2003 in Firox and Laxmi, 2016). Between 2005 and 2015 the world's cities swelled by about 750million people, per the UN. By 2050, China, India and Nigeria alone are expected to add about 900million urban residents in the mega cities of these countries. Most of the growth is experienced in Africa and Asia, specifically on the fringes of African and Asian cities. With few exceptions, cities are growing faster in size than in population. The UNFPA (2007) contends that the space taken up by urban localities is increasing faster than the urban population itself.

The urban population of Cameroon doubled within a period of 30 years after independence moving from $28.3 \%$ in 1976 to $44.3 \%$ in 2005 (Fombe \& Balgah, 2012). It was projected to be 50.6\% in 2010, 53.5\% for 2015 (projections from National Census 2005). This has resulted in rapid urban expansion of Cameroon cities such as Yaounde, Douala, Bafoussam, Limbe, Buea and Bamenda. Bamenda is a metropolis and a primate city in the North West Region of Cameroon witnessing rapid changes in land use and as a result urban sprawl at varied degrees at the detriment of its environmentally fragile lands, watersheds and the scenic beauty (Nyambod, 2010). Bamenda has transcended from being an urban center to a complex heterogeneous city rendering cross-sectorial functions and services to its inhabitants as well as its hinterland. The objective of this study is to analyze the trends of urban sprawl and land use dynamics across the three municipalities of Bamenda from 1996 to 2018 and assess the development implications inherent with this growth.

The suburbs of Bamenda I, II and III Municipalities are growing faster in size than in population and infrastructures, witnessing continues expansion of built-up and commercial land among others, resulting in the degradation of agricultural and forest lands, leading to loss of livelihood, joblessness, misery and poverty for rural dwellers. Changing lifestyle of dwellers in the rural-urban interface has equally enhanced increase degradation resulting from pollution. Extension of the built-up area and other human developments into non-developable areas (marginal lands) like very steep slopes (Sisia and Abangoh) prone to geomorphological hazards and riverine/wetland areas (Mulang and Mbelem) prone to flooding and designated as "non habitable" have increased the frequency of natural hazards. All these in contravention of the Law No 2004/003 of AVR.2002, which prohibits housing development in such areas. Sprawl in Bamenda, is not compatible with the supply of adequate infrastructures. The neighborhoods are strewn with poorly, drained, poorly connected and narrow streets among other infrastructures. The high living cost around the CBD has pushed the newly arrived into the suburbs. The need to evaluate the trend and disparities in the dimensions of land use and sprawl across the various peripheral zones of the Bamenda municipalities from 1996 to 2018 constitute the basis of this study which is hinged on the premise that land use dynamics and sprawl dominate the northeast of Bamenda compared to the northwest and the southwestern sections.

\section{Conceptual View}

The Driver-Pressure-State-Impact-Response Framework (DPSIR) and the Concept of Peri-Urban Sustainability are used to explain the causal framework. The DPSIR denotes that there, is a chain of causal links between society and the environment and focuses on the drivers, implications and measures to sustainably manage urban growth. The drivers of land use dynamics and urban sprawl are socio demographic (population growth, growth of educational institutions etc.) economic (transport development, growth in the commercial sector etc.) and political (growth in administrative institutions). The growing desire to meet such needs for shelter, food, economic and environmental concerns lead to pressure on the environment through excessive use of resources, emission of toxic chemicals and waste which alter the state of the environment. This results to loss of cultivable land, landscape degradation, soil erosion, invasion of wetlands and riverbanks, siltation, eutrophication and loss of biodiversity.

The Concept of Peri-Urban Sustainability illustrates that cities are not self-sustaining as urban dwellers and economic activities inevitably depend on environmental resources and services from outside the built environment. Land use and sprawl should be commensurate with ecological sustainability and not to undermine the integrity and health of cities as well as their carrying capacity. To enhance peri-urban sustainability in Bamenda, there is need to emphasize on the social, political, physical, economic and ecological sustainability of the environment to reduce its ecological footprints. 


\section{Study Area and Research Methodology}

\subsection{The Study Area}

The study covers the three municipalities of Bamenda (Bamenda I, II and III) in Mezam division of the North West Region of Cameroon corresponding to seven villages; (Bamendakwe, Nkwen, Ndzah, Mankon, Chomba, Nsongwa and Mbatu). Bamenda is located between latitude $5^{\circ} 56^{\prime \prime}$ and $5^{\circ} 58^{\prime \prime}$ north of the Equator and longitude $10^{\circ} 09^{\prime \prime}$ and $10^{\circ} 11^{\prime \prime}$ east of the Greenwich Meridian, situated at 1258 meters above sea level (Master Plan of Bamenda city council, 2011-2027). The town is bounded to the west by and Southwest Region, Momo division and Bali sub-division, to the north, by Bafut sub-division, to the northeast, Tubah sub-division and to the south by Santa sub-division (Figure 1).

\subsection{Research Methods}

The research designs cover the survey, correlational and historical research techniques. Primary data (household questionnaires administration, field observation and formal/informal interviews, use of photographs, as well as maps from Satellite images) were collected using the purposive random sampling techniques. Nine population clusters were identified in the three municipalities (three in each municipality), corresponding to high housing/population density zone as cluster A or Urban Core, Medium housing/population density corresponding to cluster B or Urban Fringe, and Low housing/population density as cluster C or Urban Shadow. This stratification was based on population, housing density and road network. The study was conducted in 27 neighborhoods representing the 9 clusters in Bamenda I, II, III municipalities. A total of 155 semi-structured questionnaires were retrieved out of 183 administered using the snowball technique.

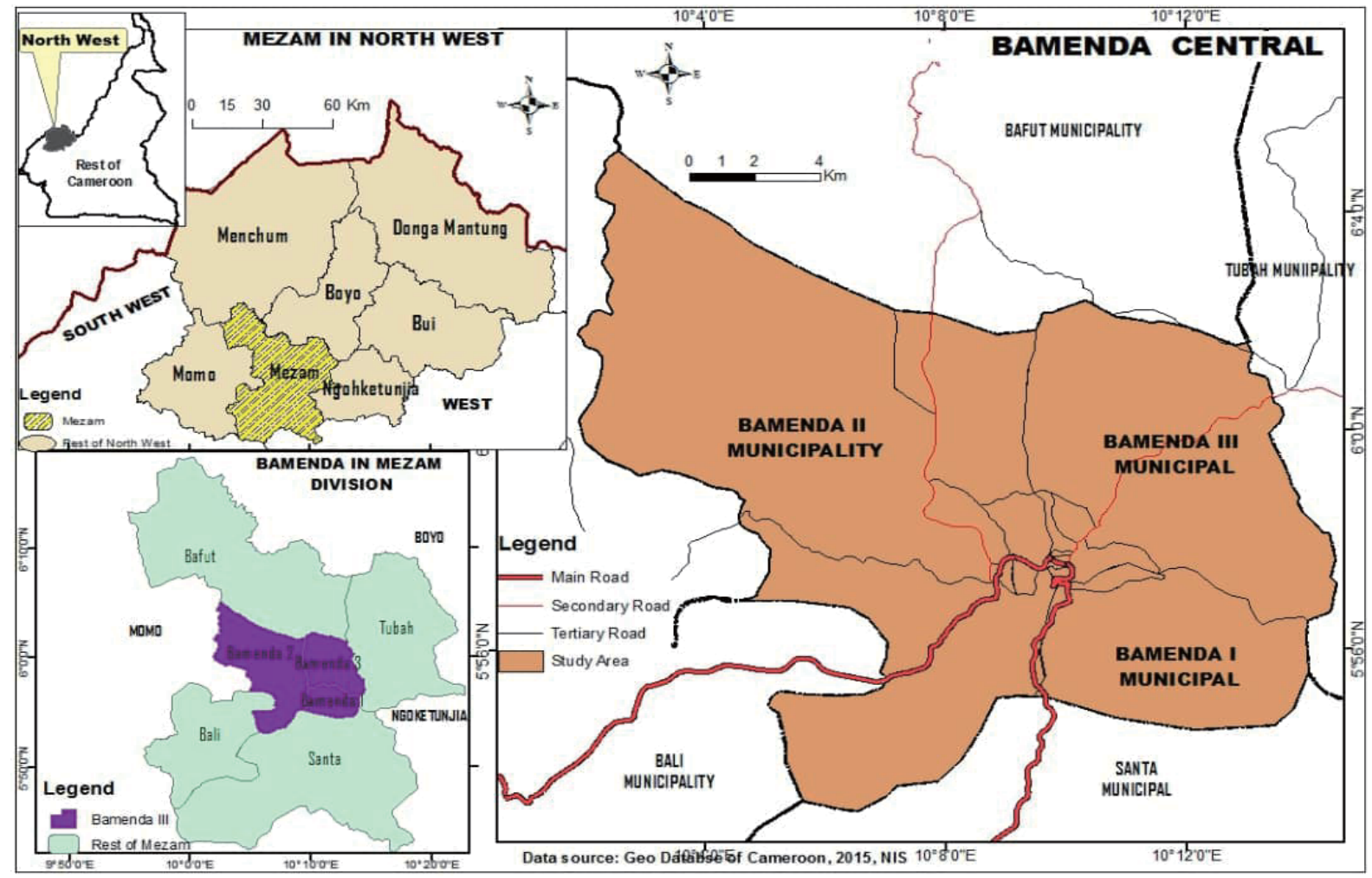

Figure 1. Location of the Bamenda municipalities in Mezam division of the north west region of Cameroon

Source: Geo-database of Cameroon 2016. NIS Yaoundé

Secondary source data included diverse literature from international scientific journals, environmental progress reports, information from internet websites, reports by governmental agencies, and NGOs, the Municipal councils, City council, the Regional Delegation of Urban Development and Housing (MINHDU), as well as the waste clearance company. The Service of School Mapping and Counseling (SMAC) at the Regional Delegation of Secondary Education (RDSE) and Annual records of schools at the Divisional Delegation of Secondary Education provided data on the evolution of schools. Landsat 5 of February 1996, Landsat 7 of January 2008 and Landsat 8 of November 2018, were downloaded from Google Earth Explorer. Processing and supervised classifications were effectuated in Erdas Image 2014, which permitted the calculation of the surface areas for each of the land uses/land cover for the three periods to produce the land use maps. Change detected from land use maps from 1996 to 2018, 
indicated the extent of sprawl and land use dynamics in the three municipalities of Bamenda. Both descriptive and inferential statistical methods were used to analyze the data. The detected changes from land use maps for 1996, 2008 and 2018 were presented on tables, and percentage of the land use change per municipality calculated for comparative analysis. The Pearson correlation analysis was employed using the Statistical Package for the Social Sciences (SPSS) Version 21 to determine the relationship between spatial expansion and loss of wetland.

\section{Results}

4.1 Trends in Peri-Urban Land Use/Land Cover Dynamics and Disparities in Urban Sprawl between the Three Municipalities from 1996 to 2018

\subsubsection{Peri-Urban Land Use / Land Cover Situation by 1996}

This is the period Bamenda city gained the status of an urban council with limited growth mainly around the CBD, while its peri-urban areas were dominated by farmlands, wetlands/gallery forest and other vegetal cover. The urban fringe and the urban shadow depicted rural characteristics at the time. Figure 2 and table 1 illustrates the state of land use and sprawl in the three municipalities of Bamenda in 1996.

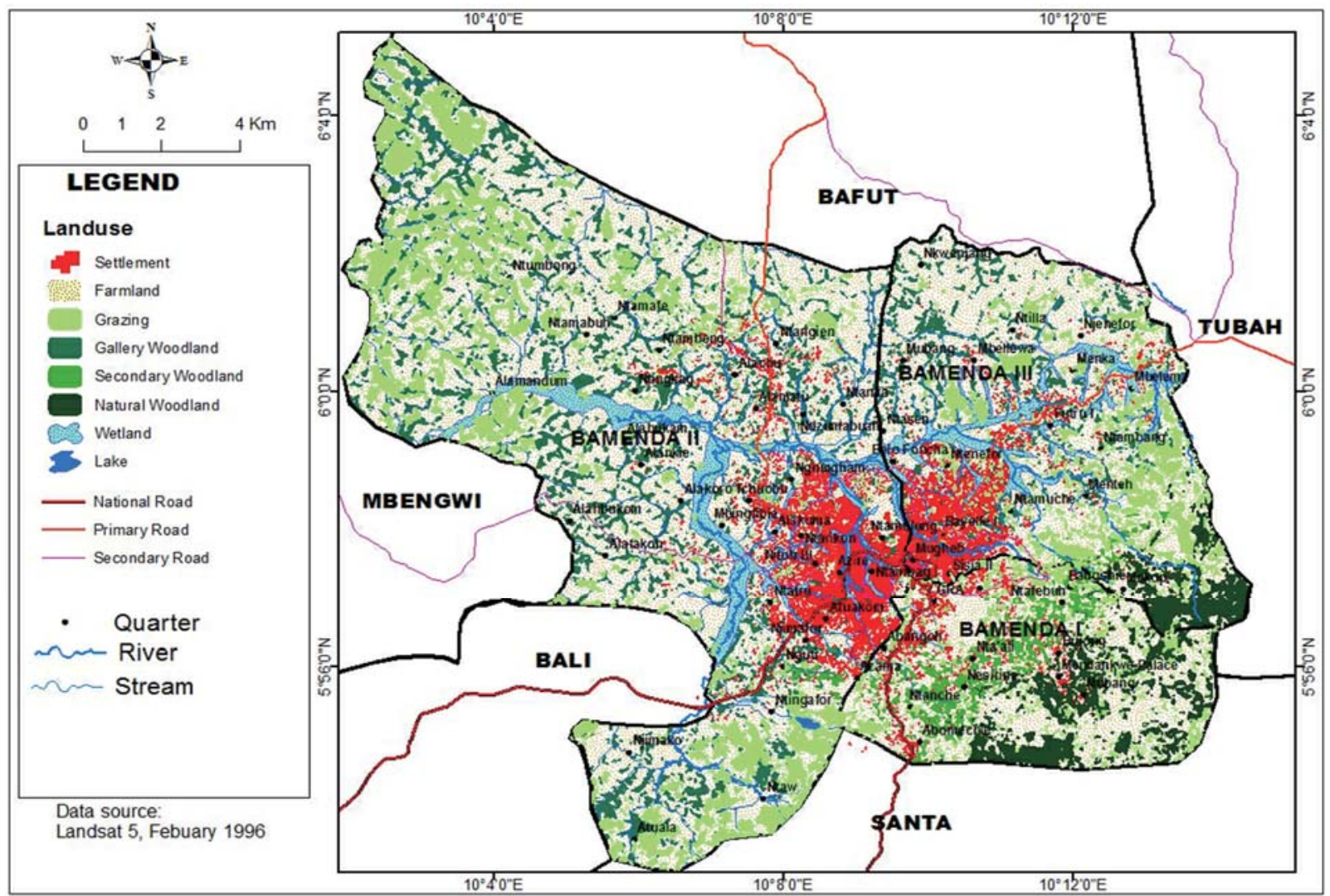

Figure 2. Land use map of Bamenda as of 1996

\subsubsection{Peri-Urban Land Use Dynamics by 2008}

Between 1996 and 2008, many developments took place such as the relocation of motor parks and travel agencies from the Centre of the town to the peripheries precisely in 2000, and the creation of the three Sub-divisional council areas (Bamenda I, II and III) in 2007. Population had grown from 137,832 in 1996 to 322,889 in 2005 (BUCREP, 2005). These urban activities accelerated land use/land cover changes as shown in figure 3 and table 1. 


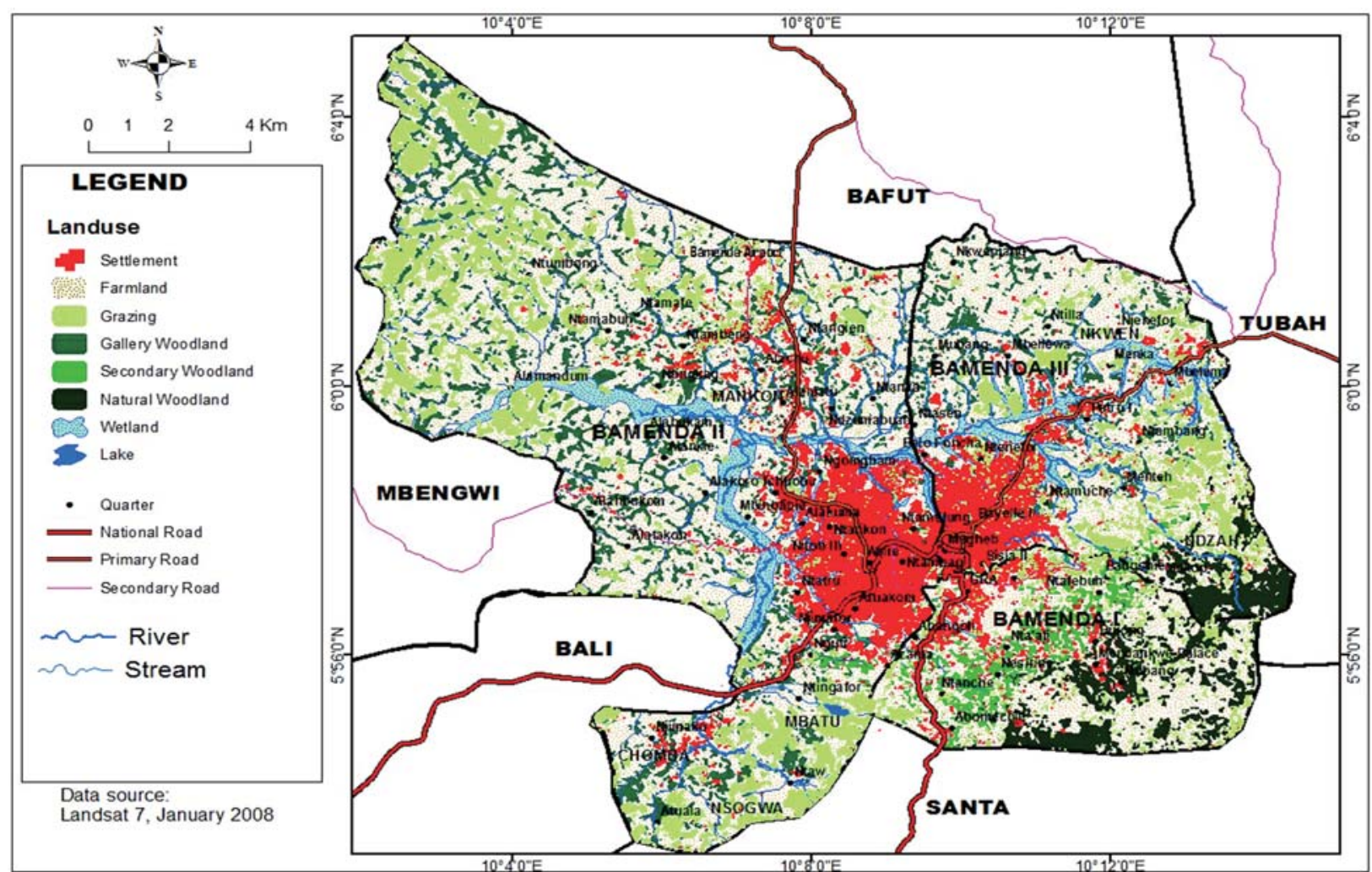

Figure 3. Land use map of Bamenda by 2008

Table 1. Land use / land cover change detection (1996-2018)

\begin{tabular}{lccccc}
\hline $\begin{array}{l}\text { Land uses land cover } \\
\text { category }\end{array}$ & $\begin{array}{c}\text { Surface in } \\
1996\left(\mathrm{~km}^{2}\right)\end{array}$ & $\begin{array}{c}\text { Area in } \\
2008\end{array}$ & $\begin{array}{c}\text { Area in } \\
2018\end{array}$ & $\begin{array}{c}\text { Change in Surface } \\
\text { 1996-2018 }\left(\mathrm{km}^{2}\right)\end{array}$ & $\begin{array}{c}\text { \% change } \\
1996-2018\end{array}$ \\
\hline Built-up & 25.49 & 32.01 & 53.6 & 28.11 & 10.26 \\
Vegetation & 113.05 & 107.43 & 102.39 & -10.66 & -3.89 \\
Farmland & 106.83 & 112.42 & 102.08 & -4.75 & -1.73 \\
Wetland & 28.43 & 21.49 & 15.73 & -12.7 & -4.64 \\
Lake & 0.17 & 0.17 & 0.17 & - & - \\
Total & 273.97 & 273.97 & 273.97 & 0 & 0 \\
\hline
\end{tabular}

Source: Calculated from land use map of Bamenda (1996-2018)

\subsubsection{Peri-Urban Land Use Dynamics of Bamenda by 2018}

The year 2018 reflects the current situation of land use dynamics in the Bamenda municipalities, with built-up areas being the most dominant land use in terms of change in surface area. This is the only land use that has experienced an increase. This period has been marked by a series of demographic, administrative and institutional transitions that produced remarkable transformations on the Bamenda landscape as shown in figure 4 and table 1 . After the creation of the three municipalities in 2007 by Presidential Decree No 2007/1171 of 24 April 2007, another Decree of $17^{\text {th }}$ January 2008 dissolved the status of the defunct Bamenda Urban Council (BUC) to the Bamenda City Council (BCC) with remarkable landscape implications. 


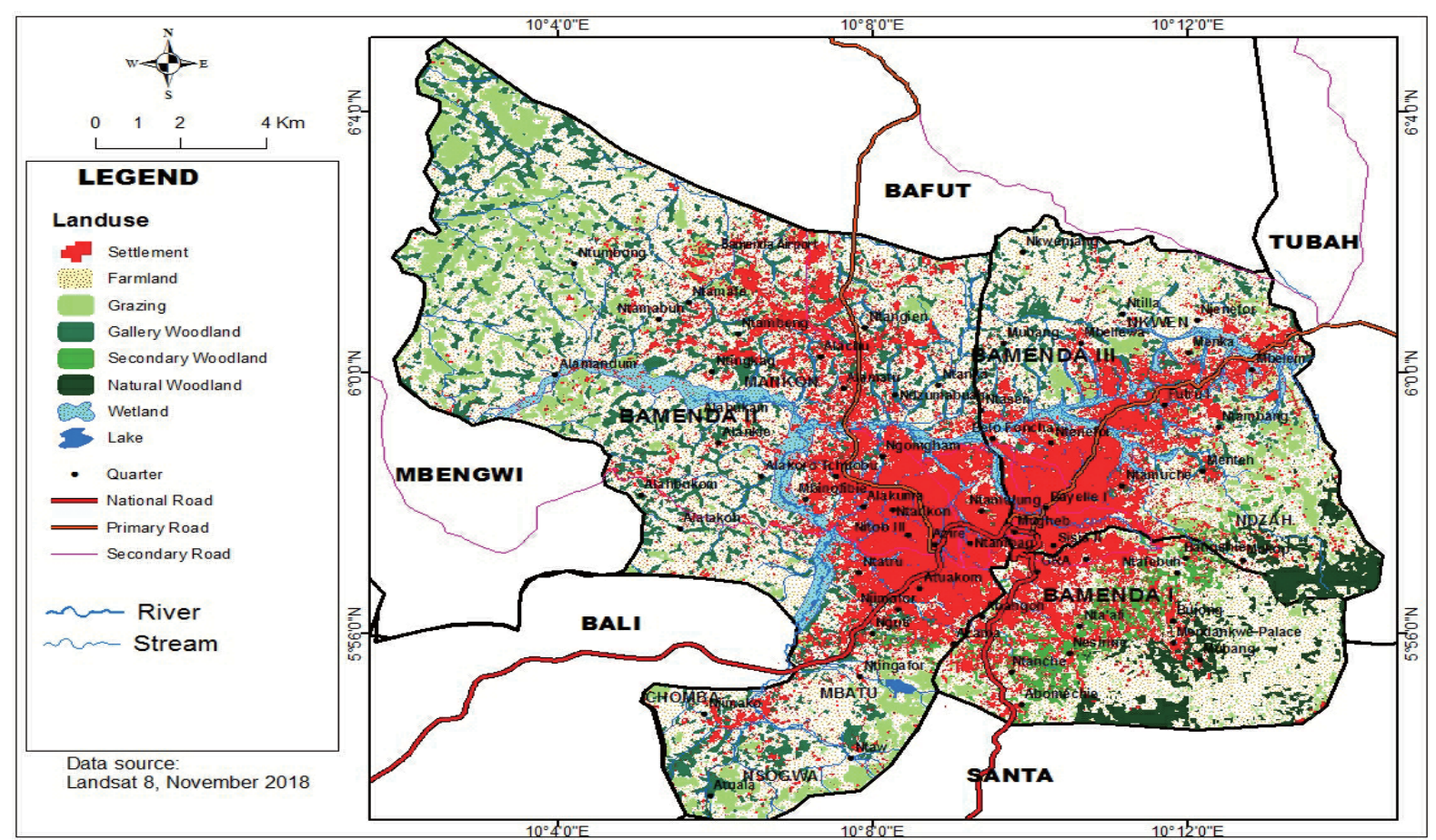

Figure 4. Land use / land cover map of Bamenda by 2018

\subsubsection{Land Use/Land Cover Change Detection of Bamenda (1996-2018)}

The period 1996 to 2018 witnessed significant land use/land cover changes as well as sprawl in the three municipalities as illustrated. Table 1 reveals that built-up area changed significantly from $25.49 \mathrm{~km}^{2}$ in 1996 to $53.6 \mathrm{~km}^{2}$ in 2018 . The change constituted approximately $28.11 \mathrm{~km}^{2},(10.26 \%)$ of the total surface area of the three municipalities. Vegetation cover on the contrary declined substantially from $113.05 \mathrm{~km}^{2}$ in 1996 to $102.39 \mathrm{~km}^{2}$ in 2018 constituting a loss in surface area of $-10.66 \mathrm{~km}^{2}(-3.89 \%)$, resulting from anthropogenic activities. Farmland declined from 106.83 in 1996 to $102.08 \mathrm{~km}^{2}$ in 2018 constituting a loss in surface area of $-4.75 \mathrm{~km}^{2}(-1.73 \%)$. Wetland recorded the highest decline from $28.43 \mathrm{~km}^{2}$ in 1996 to $15.73 \mathrm{~km}^{2}$ in 2018 constituting approximately $12.7 \mathrm{~km}^{2}(-4.64 \%)$, attributed to human encroachment.

\subsection{Disparities in Land Use Dynamics and Urban Sprawl within the Municipalities}

Land use change within the three municipalities in real terms illustrate significant differences as shown in table 2. The situation reveals significant disparities in the surface area covered by different land uses in the municipalities and their trends from 1996 to 2018. Bamenda II has recorded the largest surface coverage and exhibits more dynamics in its land use/land cover (built-up, vegetation, farmland, and wetland) than the other municipalities. Furthermore, only built-up areas recorded a significant positive change. Bamenda II, is very peculiar since it portrays the highest built-up area (14.32 $\mathrm{km}^{2}$ or $\left.5.22 \%\right)$ followed by Bamenda III $\left(8.8 \mathrm{~km}^{2}\right.$ or $\left.3.21 \%\right)$ and Bamenda I with only $4.99 \mathrm{~km}^{2}(1.82 \%)$. 
Table 2. Comparative land use/land cover change for Bamenda I, II, III from 1996-2018

\begin{tabular}{|c|c|c|c|c|c|c|}
\hline \multirow[t]{2}{*}{ Municipality } & \multirow[t]{2}{*}{$\begin{array}{l}\text { Land use/ land } \\
\text { cover category }\end{array}$} & 1996 & 2008 & 2018 & \multirow[t]{2}{*}{$\begin{array}{c}\text { Change in } \\
\text { Surface area } \\
1996-2018 \\
\left(\mathrm{~km}^{2}\right)\end{array}$} & \multirow[t]{2}{*}{$\begin{array}{c}\text { Percentage } \\
\text { change from } \\
1996-2018\end{array}$} \\
\hline & & \multicolumn{3}{|c|}{ Surface area $\left(\mathrm{km}^{2}\right)$} & & \\
\hline \multirow[t]{4}{*}{ Bamenda 1} & Built-up Area & 3.14 & 5.54 & 8.13 & 4.99 & 1.82 \\
\hline & Vegetation & 18.66 & 15.96 & 16.12 & -2.54 & -0.92 \\
\hline & Farmland & 18.92 & 19.23 & 16.48 & -2.44 & -0.89 \\
\hline & Wetland & - & - & - & - & \\
\hline \multirow[t]{5}{*}{ Bamenda II } & Built-up Area & 13.97 & 15.29 & 28.29 & 14.32 & 5.22 \\
\hline & Vegetation & 69.04 & 67.65 & 67.3 & -1.74 & -0.63 \\
\hline & Farmland & 65.80 & 68.49 & 62.91 & -2.89 & -1.05 \\
\hline & Wetland & 15.98 & 12.96 & 9.72 & -6.26 & -2.28 \\
\hline & Lake & 0.17 & 0.17 & 0.17 & - & 0 \\
\hline \multirow[t]{4}{*}{ Bamenda III } & Built-up Area & 8.38 & 11.18 & 17.18 & 8.8 & 3.21 \\
\hline & Vegetation & 25.35 & 23.82 & 18.97 & -6.38 & -2.33 \\
\hline & Farmland & 22.09 & 24.25 & 22.69 & 0.6 & 0.22 \\
\hline & Wetland & 12.45 & 8.98 & 6.01 & -6.44 & -2.35 \\
\hline Total & & 273.97 & 273.97 & 273.97 & 0.02 & 0.02 \\
\hline
\end{tabular}

Source: Calculated from land use map of Bamenda (1996-2018)

Built-up areas aside, all the other land use/land cover in the three municipalities recorded a slight decline in terms of change in surface area from 1996 to 2018. With regards to vegetation, Bamenda III has recorded the highest decline of $-6.38 \mathrm{~km}^{2}(-2.33 \%)$ followed by Bamenda I with $-2.54 \mathrm{~km}^{2}(-0.92)$, while Bamenda II recorded the least with $-1.74 \mathrm{~km}^{2}(-0.63 \%)$. As regards farmland, all the municipalities witnessed a seemingly low decline compared to wetlands whereby Bamenda III recorded a comparatively higher decline of $-6.38 \mathrm{~km}^{2}(-2.33 \%)$ than Bamenda II with $-6.26 \mathrm{~km}^{2}(-2.28 \%)$. It is obvious that Bamenda II (the northwestern peri-urban direction) exhibits rapid changes in its land use, representing 5.22\% in built-up area, compared to $3.21 \%$ for Bamenda III and $1.81 \%$ for Bamenda I.

\subsubsection{Land Use Activities in the Three Municipalities of Bamenda}

This study took note of some dominant land use activities in the three municipalities whose magnitude were used to compare the extent of the dynamics. Table 3 illustrates the disparities in dominant land use type in the different peri-urban zones of Bamenda I, II \& III. It reveals that the intensification of land use activities is highest for Bamenda II. Traffic volume was used to examine the daily flow of population into and out of the area and number of educational institutions within the various municipalities. Bamenda II indicated the highest values (39.46\%) compared to Bamenda II and I ( $34.37 \%$ and $26.17 \%$ respectively). The disparity in density of land use activities have a corresponding influence on the extent of land use changes, activities and sprawl.

Table 3. Dominant land use and other activities in the peri-urban zones

\begin{tabular}{lccc}
\hline Land use activities & Bamenda I & Bamenda II & Bamenda III \\
\hline Built-up areas** & $8.13 \mathrm{~km}^{2}$ & $28.29 \mathrm{~km}^{2}$ & $17.18 \mathrm{~km}^{2}$ \\
Urban agriculture $* *$ & $16.48 \mathrm{~km}^{2}$ & $62.91 \mathrm{~km}^{2}$ & $22.69 \mathrm{~km}^{2}$ \\
Volume of traffic* & 6162 & 9297 & 8097 \\
Number of Educational institutions*** & 5 & 31 & 17 \\
\hline
\end{tabular}

Source: *Fieldwork 2018/2019, **Data from land use maps of 2018, ***Annual records of schools 2017/2018

Figure 5 reveals that in 1996, built-up areas concentrated in the urban core, and over time, the process of urbanization that characterizes most third world cities, has led to their expansion to the peri-urban zones. It is evident that urban expansion is extremely high in Bamenda II (the northwest), although the rate of expansion differs based on traffic flow to the suburb. Data was collected on the circulation of different types of fleets during low and high peak periods in the city to reveal the dominant direction of urban expansion in Bamenda. 


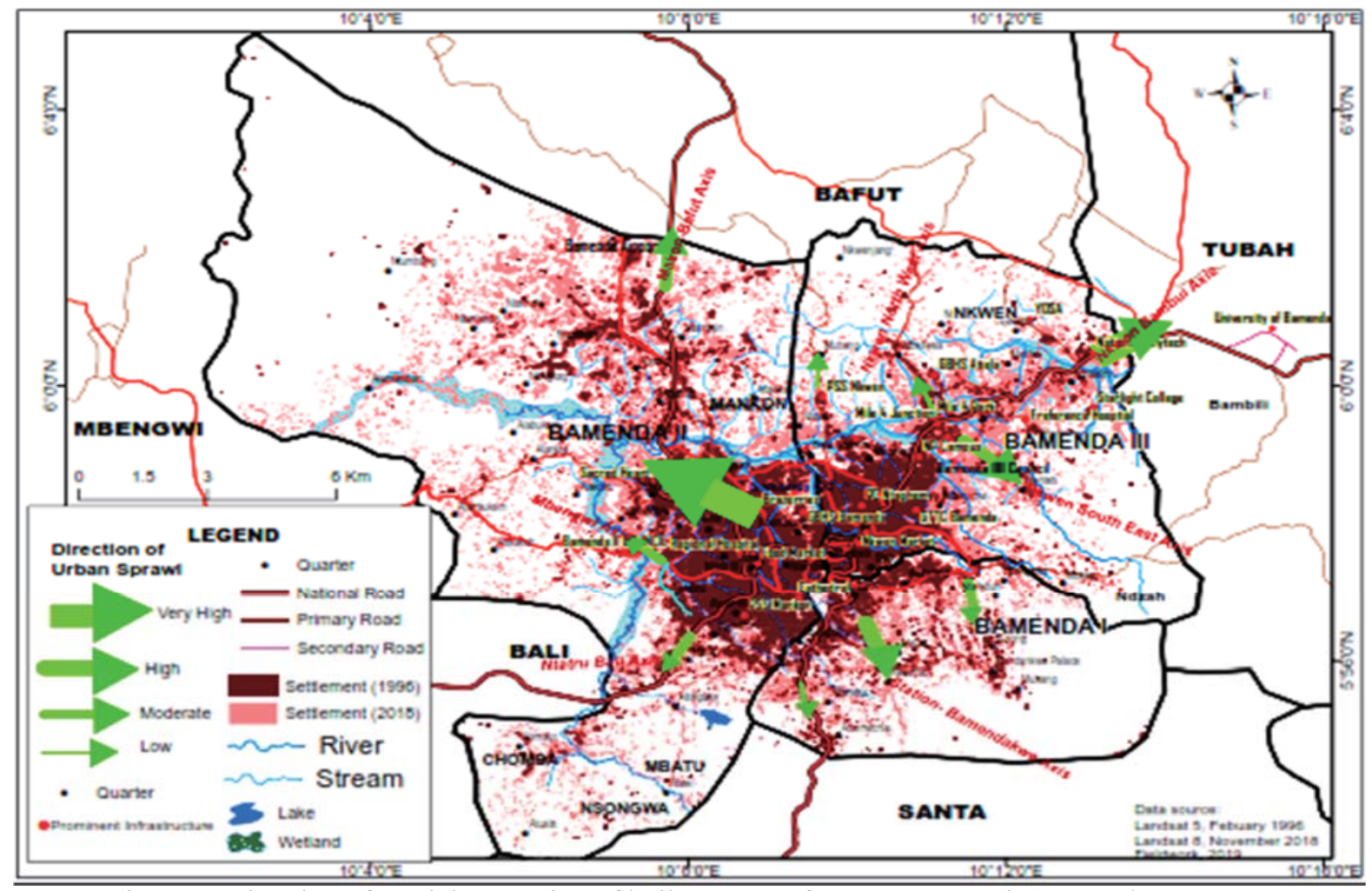

Figure 5. Direction of spatial expansion of built-up areas from 1996-2018 in Bamenda I, II \& III

The disparity in the volume of traffic flow to and from the various peri-urban directions indicate that the volume of traffic flow of 9,297 is highest from the CBD towards Bamenda II municipality in the northwest of the town compared to 8,097 and 6,162 respectively from the CBD to Bamenda III and I. The volume differs for the three directions corresponding to greater land use activities acting as drivers of development and activities represented by urban sprawl.

\subsubsection{Urban Sprawl and Planning Implications}

The unprecedented rate of urban sprawl has a direct bearing on the effectiveness of planning in the peripheries. To investigate the level of planning in the three municipalities, indicators of planning such as the degree to which housing development comply to building code (Plate 1), access to basic social facilities like water, electricity, transportation, education, health services and increase development of standard housing in the context of urban sprawl were of prime concern. Four options were considered to understand the population's perception of the nature of urban growth with respect to planning. Majority (56.77\%) of the population based on questionnaires and interviews noted that recent anthropogenic activities of the municipalities are unplanned. $32.9 \%$ consider it planned and $8.39 \%$ perceive it to be haphazard and spontaneous, while $1.9 \%$ of the sampled population were ignorant. 

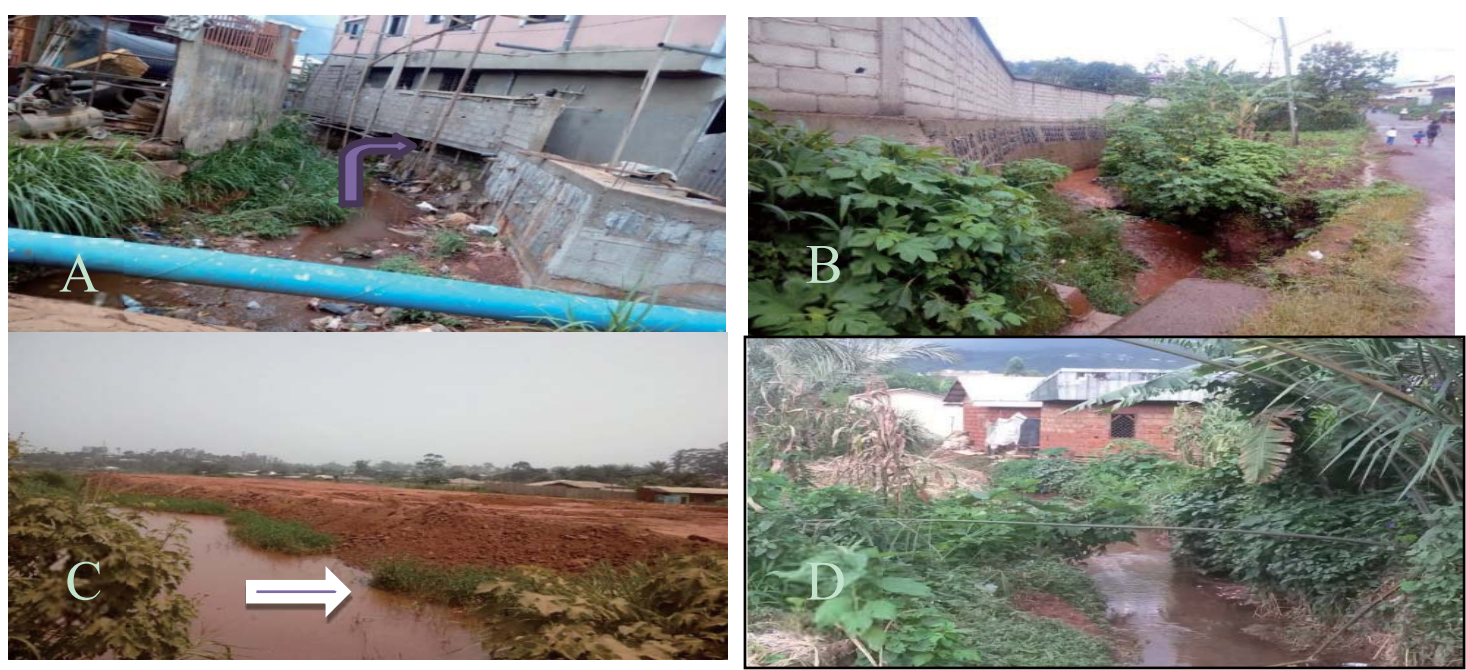

Plate 1. Human encroachment on riverbeds. Note the vertical overlapping of the structure over the stream channel in plate $\mathrm{A}$, the reclamation in plate $\mathrm{C}$ causing siltation of the riverbed and $\mathrm{D}$ is a home constructed on the riverbed, less than 2 metres from the river channel

Source: Acha, May 2019

Table 5 illustrates the relationship between urban sprawl and wetlands in Bamenda, correlated using built-up and wetland areas for 1996, 2008 and 2018.

Table 5. Pearson correlation test results

\begin{tabular}{|c|c|c|c|}
\hline \multicolumn{4}{|c|}{ Pearson Correlations } \\
\hline Variables $\left(\mathrm{Km}^{2}\right)$ & Statistics & Urban sprawl & Wetland loss \\
\hline \multirow{3}{*}{ Urban sprawl } & Pearson Correlation & 1 & -.959 \\
\hline & Sig. (2-tailed) & & .183 \\
\hline & $\mathrm{N}$ & 3 & 3 \\
\hline \multirow{3}{*}{ Wetland loss } & Pearson Correlation & -.959 & 1 \\
\hline & Sig. (2-tailed) & .183 & \\
\hline & $\mathrm{N}$ & 3 & 3 \\
\hline
\end{tabular}

With an $\mathrm{r}$ value of -0.959 , there is a strong negative relationship between urban sprawl $\left(\mathrm{Km}^{2}\right)$ and wetland loss in the Bamenda Municipalities. However, a P-value of $<0.05$ reveals that this result is not statistically significant. The strong negative correlation implies that the variables increase in opposite directions. Hence, an increase in urban sprawl within the three-year period in Bamenda I, II \& III has been accompanied by declining coverage of wetlands.

\section{Discussions}

Statistics from land use maps reveal that built-up for the three municipalities increased from $25.49 \mathrm{~km}^{2}$ in 1996 to $28.11 \mathrm{~km}^{2}$ in 2018 (10.26\% change). Bamenda II which is in the northwestern peri-urban direction exhibits greater changes in land use, producing the highest percent of sprawl (5.22\% change in built-up), resulting from its intensity of land use activities. It is closely followed by Bamenda III (3.21\%), with Bamenda I being the least. This can be attributed to the large population and surface coverage, a relatively gentle topography greater accessibility and more social amenities (schools, health unites, etc.) compared to Bamenda I and III municipalities, based on analysis from questionnaires, interviews and field observations. This corroborates the ideas of Balgah and Nformi (2017), who observed that rapid increase in the population of Tubah (a neighboring subdivision to Bamenda II) is the main driver of land use/cover dynamics. Furthermore, it has been realized that sprawl is more evident in areas with several wetlands, which the population exploit for its cheapness, availability though vulnerable to floods. These are areas which the law prohibits for urban structures but paradoxically have become the immediate spaces for 
urban expanding infrastructures in the peripheries of Bamenda II especially as this municipality lies at the foot of the Bamenda escarpment which falls in part of Bamenda I with limited wetlands.

This explains too why farmlands, wetlands, and vegetal cover record the highest decline at the suburbs. The growth in built up areas at the expense of these land uses reinforces the findings of Torren and Alberti (2000), Barnes et al., (2001) in Firox and Laxmi (2016), who noted that although urban growth is an indicator of social, economic and political growth, it is also at the cost of forest, agricultural land, orchards and greenery of the city. This can also be corroborated with the findings by Olayiwola, Eludoyin and Ekecha (2011) in Taniform (2016), who revealed that the increase in the aerial extent of settlements closes the gap between the forest and built-up area, thus easing the removal of forest ecosystems by humans at the fringe zones. This is also in conformity with the view of Fombe and Balgah (2012) who noted that in the face of expanding urban areas in Cameroon, the protection of land is limited with over $60 \%$ of the most productive agricultural land converted to urban land uses but without a corresponding improvement in planning within these sprawling environments.

\section{Conclusion}

Bamenda city suffers from continuous haphazard densification of the town's fabric from the city centre outwards. The spatio-temporal analysis of land use dynamics and urban sprawl in the three municipalities of Bamenda from 1996 to 2018 indicates significant changes in land use/land cover, with observed decline in farmland, vegetation and wetland. Rapid changes take place at different intensities based on the nature and type of available space at the periphery and its surrounding population. Such rapid spatial expansion is not concomitant with city planning and developmental norms as epitomized by Bamenda II which is portrayed as the fastest sprawling municipality. This has culminated in numerous environmental and socio-economic implications, with some dominant implications being the occupation of wetlands, risky zones, uncoordinated urban growth, congestion and uncontrolled urban expansion.

If the present urban sprawl is not contained in the medium-term, the spatial coverage of built-up areas will lead to a merging with its satellite towns like Bambui-Bambili, Bali, and Bafut as growth along the arterial corridors is limitless. This may trigger more land use conflicts and aggravate developmental problems. It is imperative to realize that the cities we build and the urban lifestyle we lead today will profoundly affect the chances of future generations to shape their own environments.

\section{References}

Acha, M. (2019). A Comparative Study of Land Use Dynamics and Urban Sprawl in the Bamenda Municipalities of the North-West Region of Cameroon, Unpublished MSc Thesis, The University of Bamenda.

BUCREP. (2005). Third General Population and Housing Census: $3^{\mathrm{è}}$ RGPH, Rapport De Présentation des Résultats Définitif; Résumé, 2010.

City Council. (2012). Building Regulations of the Master Plan of Bamenda City 2011-2027; Human Technology Resources (HTR) Cameroon, consultants May, 2012.

Douglas, M. (2017). Where is the world's most sprawling city? Rockfeller Foundation, the Guardian, (16 pages).

Dutta, V. (2012). Land Use Dynamics and Peri-urban Growth Characteristics: Reflections on Master Plan and Urban Suitability from a Sprawling North Indian City. Environment and Urbanization, Asia, 3(2), 277-301. https://doi.org/10.1177/0975425312473226

Firox, A., \& Laxmi, G. (2016). Analysis of Urban Sprawl Dynamics Using Geospatial Technology in Ranchi City, Jharkhand, India. Journal of environmental geography, 9(1-2), 7-13. https://doi.org/10.1515/jengeo-20160002

Fombe, L. F., \& Balgah, S. N. (2012). The urbanization process in Cameroon: Patterns, Implications and prospects. Nova Science Inc. New York; USA.

Herbert, G. (1999). Creating Sustainable Cities, Schumarcher Breifing No 2. Green Books for the Schmacher Society.

Kimengsi, J. N., Balgah, S. N., \& Achia, S. N. (2017). Peri-Urban Land Use Dynamics and Development Implications in the Bamenda III Municipality of Cameroon. Retrieved July 3, 2017, from www.scholink.org/ojs/index.php/se

Kombe, W. J. (2003). Land use dynamics in peri-urban areas and their implications on the urban growth and form: The case of Dares Salaam, Tanzania. Habitat International, 29(1), 113-135. https://doi.org/10.1016/S01973975(03)00076-6

Kometa, \& Ndi, R. A. (2012). The Hydro-geomorphological Implications of Urbanization in Bamenda, Cameroon. Journal of Sustainable Development, 5(6). https://doi.org/10.5539/jsd.v5n6p64 
Law No. 2004/003 of 21AVR.2004 to regulate Town Planning in Cameroon.

Master Plan of Bamenda City Council (2011-2027); Detailed Physical Development Plan, Consultant HTR, May, 2012.

Ngoran, S. D., \& Xue, X. (2013). The Socioeconomic and Environmental Implications of Urban Sprawl on the Coastline of Douala-Cameroon. Options for Integrated Coastal Management, Published Master's Thesis, University of Buea.

Ngoran, S. D., \& Xue, X. (2015). Addressing urban sprawl in Douala, Cameroon: Lessons from Xiamen integrated coastal management. Journal of Urban Management. https://doi.org/10.1016/j.jum.2015.05.001

Nyambod Emmanuel, M. (2010). Environmental Consequences of Rapid Urbanization: Bamenda City of Cameroon. Journal of environmental protection, 1, 15-23. https://doi.org/10.4236/jep.2010.11003

Taniform E. A. (2016). Peri-Urban Dynamics and Implications in the Bamenda III Municipality of the North West Region of Cameroon, Unpublished M.Sc. thesis, University of Buea.

UNCHS HABITAT. (2001). The State of the World's Cities Report 2001. United Nations Center for Human Habitat Nairobi, 2001.

UNEPA. (2007). State of the world Population 2007. Unleashing the potential of Urban Growth, United Nations population Fund, 220 East 43nd Street, $23^{\text {rd }}$ FI. New, 220 East 43nd Street, $23^{\text {rd }}$ FI. New York, NY10017 U.S.A.

\section{Copyrights}

Copyright for this article is retained by the author(s), with first publication rights granted to the journal.

This is an open-access article distributed under the terms and conditions of the Creative Commons Attribution license (http://creativecommons.org/licenses/by/4.0/). 